\title{
The genesis of climate change activism: from key beliefs to political action
}

\author{
Connie Roser-Renouf • Edward W. Maibach • \\ Anthony Leiserowitz $\cdot$ Xiaoquan Zhao
}

Received: 23 April 2012 / Accepted: 31 May 2014 / Published online: 20 June 2014

C) The Author(s) 2014. This article is published with open access at Springerlink.com

\begin{abstract}
Climate change activism has been uncommon in the U.S., but a growing national movement is pressing for a political response. To assess the cognitive and affective precursors of climate activism, we hypothesize and test a two-stage information-processing model based on social cognitive theory. In stage 1, expectations about climate change outcomes and perceived collective efficacy to mitigate the threat are hypothesized to influence affective issue involvement and support for societal mitigation action. In stage 2, beliefs about the effectiveness of political activism, perceived barriers to activist behaviors and opinion leadership are hypothesized to influence intended and actual activism. To test these hypotheses, we fit a structural equation model using nationally representative data. The model explains 52 percent of the variance in a latent variable representing three forms of climate change activism: contacting elected representatives; supporting organizations working on the issue; and attending climate change rallies or meetings. The results suggest that efforts to increase citizen activism should promote specific beliefs about climate change, build perceptions that political activism can be effective, and encourage interpersonal communication on the issue.
\end{abstract}

\section{Introduction}

A recent analysis attributes the failure of U.S. cap-and-trade legislation in 2010 to the lack of a broad-based national movement, and argues that legislation is unlikely without a large, wellorchestrated and sustained climate movement (Skocpol 2013). Citizen activism, it has been suggested, is the most efficacious method of achieving emission reductions, given that governments are unlikely to enact carbon limits without public pressure and individual conservation alone is incapable of producing sufficient emission reductions (Ockwell et al. 2009).

Electronic supplementary material The online version of this article (doi:10.1007/s10584-014-1173-5) contains supplementary material, which is available to authorized users.

C. Roser-Renouf $(\bowtie) \cdot$ E. W. Maibach $\cdot$ X. Zhao

Center for Climate Change Communication, George Mason University, Fairfax, VA, USA

e-mail: croserre@gmu.edu

A. Leiserowitz

Project on Climate Change Communication, Yale University, New Haven, CT, USA 
Climate activism has been relatively infrequent in the U.S.: In 2012, 11 percent of Americans contacted an elected official in support of mitigation policies, and 16 percent supported an organization working to reduce global warming (Leiserowitz et al. 2012a). Yet the majority of Americans believe global warming is occurring and say they are worried about it (Leiserowitz et al. 2012b).

The science communication community has recognized that a simple presentation of the scientific facts does not necessarily motivate public engagement, and meta-analysis has shown that science literacy is only weakly correlated with public attitudes toward controversial scientific issues such as climate change (Allum et al. 2008). Values and motivated reasoning may bias information-seeking, interpretation and response to scientific issues (Kahan et al. 2010; Kunda 1990), and communicators have been advised to convey climate information in ways that connect with audience values, increase the issue's relevance by emphasizing local consequences, and emphasize the co-benefits of emission reductions (Maibach et al. 2008; Myers et al. 2013; Bain et al. 2012).

These approaches may enhance public receptiveness to the issue, but in this paper we argue that at least some understanding of both the threat and its potential solvability do matter and are important predictors of support for climate action, even when values are taken into account. We also propose that activism is currently constrained by public beliefs that political activism is ineffective. To assess these propositions, we develop and test a two-stage informationprocessing model of climate activism using a nationally representative survey of American adults.

\section{Theoretical framework}

Our two-stage information-processing model of climate activism is grounded in social cognitive theory (Bandura 1986, 1977), which posits that people's behaviors are influenced by their expectations about the likelihood and desirability of the outcomes associated with actions - outcome expectations - and their perceived ability to perform those actions - efficacy perceptions. The pertinent forms of expectation and efficacy for this analysis are risk perceptions - outcomes expected in the absence of climate change mitigation; response efficacy - belief that actions to reduce a threat will be effective; self-efficacy - belief that one is capable of performing an action and collective efficacy - belief that one's group is capable of acting together to achieve a shared goal (Bandura 2000; Witte and Allen 2000).

We propose that outcome expectations and efficacy perceptions influence people's responses to climate change in two ways: First, people who hold negative climate change outcome expectations (high risk perceptions), and who believe in humanity's collective potential to reduce the threat (high collective efficacy) will develop beliefs that societal mitigation action should occur and the emotional involvement necessary to motivate behavior.

People will then evaluate their response options. Those who believe that legislators will be responsive to citizen activism (high response efficacy), and who feel capable of engaging in activist behaviors (high self-efficacy) will be more likely to act.

Activism response and self-efficacy are hypothesized to be influenced by two factors: People with a history of civic engagement and opinion leaders - people who communicate frequently about the issue and exercise social influence on it - may have greater confidence in their ability to act effectively.

Studies from diverse theoretical perspectives support our hypothesized social-cognitive model, shown in Fig. 1. Below, we connect the model to related constructs in the literature. 


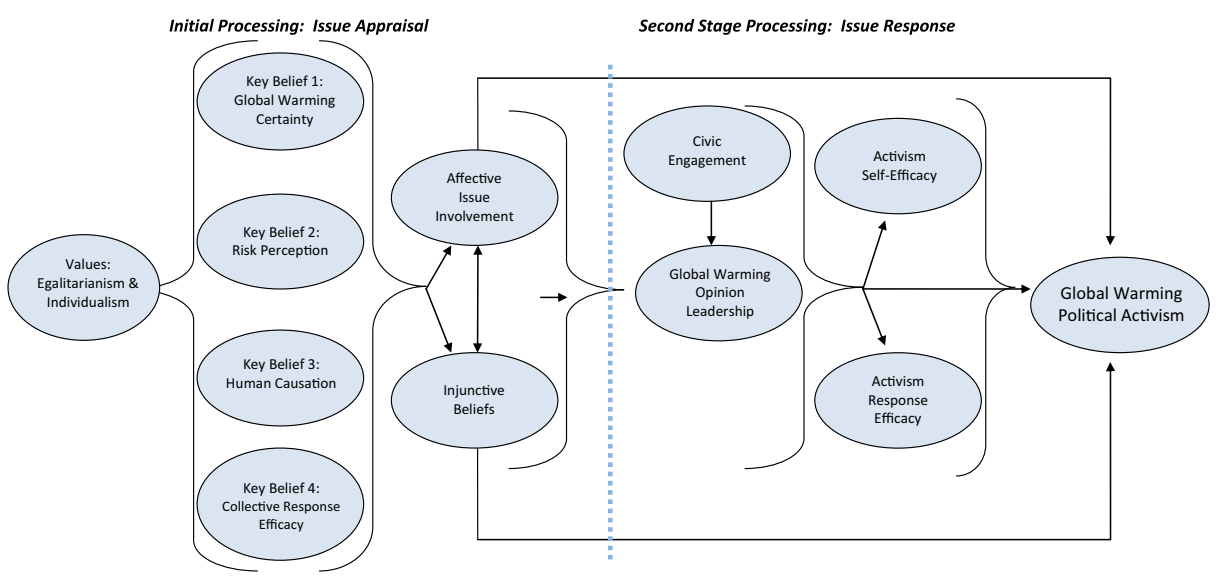

Fig. 1 Theoretical Social-Cognitive Model of Political Activism for Climate Change Mitigation

\section{Initial processing: issue appraisal}

\subsection{Outcome expectations}

Negative outcome expectations for the environment have been identified as a primary precursor to environmental activism in multiple studies (Stern et al. 1999; Lubell 2002; Lubell et al. 2007). On average, however, Americans have viewed climate change as only moderately harmful, and their level of perceived threat has been closely related to cultural values: For egalitarians, the threat to the health and safety of others enhances climate concern, while for individualists, the perceived threat to individual freedoms from government policies attenuates climate concern and generates doubt and disbelief about climate change itself (Leiserowitz, 2005).

\subsection{Efficacy perceptions}

Low efficacy has been shown to be a significant barrier to climate action, manifesting as avoidance, helplessness and denial (Stoll-Kleeman et al. 2001; Lorenzoni et al. 2007; Ockwell et al. 2009). From a social cognitive perspective, this presents a significant barrier to positive action; fear alone, as Bandura (1986) writes, can backfire - an assertion supported by research on fear appeals using the Extended Parallel Process Model (EPPM; Witte and Allen 2000).

According to the EPPM, upon perceiving a potentially threatening outcome, individuals assess its severity and their susceptibility. If either is perceived as low, threat processing stalls and no response is elicited. Conversely, as individuals' perceptions of severity and susceptibility increase, they experience fear, which motivates an evaluation of the effectiveness and feasibility of recommended responses to reducing the threat - i.e., response efficacy and self-efficacy.

When fear of a threatening outcome is high and response or self-efficacy is low, people employ coping responses that reduce their fear, but not the threat - e.g., defensive avoidance, denial, and issue/message derogation. In contrast, when efficacy is high, people adopt intentions and behaviors aimed at reducing the threat.

Studies that have examined climate change outcome expectations and efficacy beliefs together have shown that both predict climate change attitudes and behaviors (Krosnick 
et al. 2006; Lubell 2002: Lubell et al. 2007). These studies do not explicitly situate themselves within social-cognitive theory or cite the EPPM, but each includes the key concepts discussed above, and can thus be interpreted in light of the current discussion.

Of greatest relevance to the model tested here, Krosnick and colleagues (2006) found that perceptions of the seriousness of global warming as a national issue were predicted by: (1) Certainty that global warming is occurring; (2) certainty that it will have negative consequences; (3) recognition that humans are causing the problem, and (4) belief that humans can reduce the threat. The first two of these beliefs may be understood as outcome expectations regarding a threatening outcome, while the second two assess collective efficacy for reducing the threat. ${ }^{1}$

3.3 Issue involvement and injunctive beliefs as mediators between initial and second-stage processing

Issue involvement increases attention to an issue (Petty and Cacioppo 1986) and behavior change (Chaffee and Roser 1986); it is a precursor to opinion leadership (McLeod et al. 1999), political participation (Brady et al. 1995) and activism (Schwebel 2008). We hypothesize that understanding the threat of climate change and recognizing its potential for reduction will generate affective issue involvement and injunctive beliefs, i.e., beliefs that societal action should be taken to reduce the threat. ${ }^{2}$ This will motivate an evaluation of available methods to reduce the threat, moving people into a second-stage of processing.

\section{Second stage processing}

\subsection{Activism response efficacy}

Numerous studies have examined the factors underlying political and social movement participation. Brady and colleagues (1995) identified three classes of political participation predictors: Resources, including time, money, and skills; issue engagement, including involvement and the perceived effectiveness of actions; and social proximity to activist networks. Klandermans (2004) found that people typically participate in social movements to influence society or politics; strengthen personal identity through membership in an admired group; and/or derive meaning from the movement's ideology. For those who participate primarily to promote social change, participation hinges on beliefs that activism is effective, can succeed, and that one's participation will increase the likelihood of success (Burstein et al. 1995; Finkel et al. 1990) - i.e., high response efficacy. In the case of climate change activism, these are likely barriers: Multiple polls report that Americans believe legislators ignore public opinion

\footnotetext{
${ }^{1}$ Recognition of human causation forms the basis for collective response efficacy: If humans were not causing climate change and recent changes in the climate were being caused by natural environmental cycles, then human ability to reduce climate change would be doubtful.

${ }^{2}$ Our measures and conceptualization of injunctive beliefs are similar to the personal normative beliefs contained in the VBN model (Stern et al. 1999). The VBN construct focuses on beliefs about what should be done by society and by the respondent personally. Our construct is similar, but does not include the personal dimension of the construct, focusing instead on respondents' desired response from government, corporations and citizens. The collective focus of our measures reflects the importance of collective action on climate change. We have renamed the construct "injunctive beliefs," given the strong focus on what should occur.
} 
and act based on the wishes of campaign contributors (Pew 2007; Leiserowitz et al. 2013).

\subsection{Self-efficacy and civic skills}

Prior experience with political participation and civic engagement on other issues can be expected of climate activists: Exercising one's skills is intrinsically satisfying and an important driver of the actions people choose (Bandura 1986). Civic skills and political interest are the strongest predictors of political activities requiring a commitment of time, but not money (Brady et al. 1995), and participation fosters positive outcome expectations, enhanced self-efficacy, opinion leadership and further participation (Shah and Scheufele 2006).

Demographic differences in U.S. political participation may be understood as proxies for civic skills: Education is the strongest distinguishing factor; occupation, income, gender, and race are related to political participation as well, although gender differences are declining, and racial differences are explained by education and historical obstacles created to reduce minority participation (Verba et al. 1995).

Opinion leadership, like civic engagement, is associated with high self- and response efficacy for political participation (Weimann 1991, Scheufele and Shah 2000). Opinion leaders' anticipation of positive results from their own actions is not unfounded: Legislators respond more to opinion leaders than to other members of their constituencies (Adams and Ezrow 2009).

\section{Proposed model of climate activism}

Integrating the literature discussed above, we developed the two-stage information-processing model of climate activism shown in Fig. 1. In the initial phase, the individual cognitively appraises climate change, assessing its dangers and solvability, guided, in part, by cultural values. In the second phase, those who have concluded that climate change is both dangerous and solvable assess whether political activism is an effective and feasible method of reducing the danger.

The initial appraisal focuses on the key beliefs identified by Krosnick and colleagues - certainty that climate change is occurring, poses a dangerous threat, is caused by humans, and may be reduced by humans. In turn, holding these beliefs is hypothesized to generate affective involvement with the issue and injunctive beliefs that action should be taken by a variety of societal actors - government, corporations and individuals.

We expect that involvement, injunctive beliefs and a history of civic engagement together will predict global warming opinion leadership, as evidenced by more interpersonal communication on the issue, enjoying this communication, and giving advice. Opinion leadership should be associated with higher political self-efficacy, given the communicative competence and confidence opinion leadership reflects, as well as stronger belief in the effectiveness of political activism, i.e., higher activism response efficacy.

Finally, we hypothesize that climate activism - both actual and intended - is predicted by six variables: Affective involvement with the issue; injunctive beliefs that action should be taken; a history of civic engagement; global warming opinion leadership; activism response efficacy; and political self-efficacy. 


\section{Methods $^{3}$}

Data for this study were obtained from a nationally representative survey conducted in October and November, 2008; respondents were adult members of an online, non-volunteer, probability-based panel with 50,000 members. The study had a recruitment rate of $21.6 \%$, a profile rate of $56.4 \%$, a completion rate of $54.1 \%$, and a cumulative response rate of $6.6 \% ; N=2,164$.

\subsection{Measurement}

Climate change activism was assessed for three actions - contacting elected officials to support mitigation action; attending climate-related rallies or meetings; and donating to or volunteering with an organization working to reduce global warming. For each behavior, a seven-point scale was constructed, integrating past actions and future intentions from (1) intention to act less frequently in the coming year ${ }^{4}$ to (7) has acted more than once and intends to do so more frequently in the coming year; Cronbach's $\alpha=.81$ for the three scales. ${ }^{5}$

Values: Four Likert-type measures were used to assess egalitarianism $(\alpha=.72)$ and four were used to assess individualism $(\alpha=.77)$.

Key beliefs: (1) Belief certainty regarding the reality of global warming was assessed with a nine-point scale ranging from (1) complete certainty that global warming is not occurring; to (5) don't know; to (9) complete certainty that it is occurring.

(2) Risk perception was measured with a 23 -item standardized index that assessed who is threatened by climate change; what types of impacts climate change will cause; how probable several impacts of climate change are; and when climate change will begin to harm people $(\alpha=.97)$.

(3) Belief in human causation was assessed as a dichotomy - the respondent does or does not recognize that humans are causing global warming.

(4) Collective efficacy: The belief that global warming is solvable was assessed with a 5point scale from (1) Global warming isn't happening to (5) Humans can reduce global warming, and are going to do so successfully.

Affective issue involvement was assessed by two items: Worry about global warming was assessed on a 4-point scale from "not at all worried" to "very worried"; and personal importance was assessed on a 5-point scale from "not at all important" to "extremely important" $(\alpha=.87)$.

Injunctive beliefs were assessed with seven 5-point items asking whether a variety of societal actors should be doing more or less to reduce global warming: Local government officials; state legislators; governors; the U.S. Congress; the president (Bush); corporations and industry; and citizens themselves $(\alpha=.97)$.

Civic engagement was assessed by asking which, if any, of 11 political activities the respondent had engaged in over the prior year, such as attending meetings, writing letters, or working for a political party $(\alpha=.72)$.

\footnotetext{
${ }_{3}^{3}$ Methods and measurement are summarized very briefly here; details are available in Supplementary Materials.

${ }^{4}$ Almost all respondents who intend to act less frequently have not acted previously $(97 \%)$; this does not make logical sense, but was the pattern in the data.

${ }^{5}$ Cronbach's $\alpha$ assesses the reliability of an index and ranges from 0 to 1 . A rule-of-thumb for acceptable levels of alpha is .6 or higher.
} 
Global warming opinion leadership was measured using five items. Respondents were asked whether they liked to discuss global warming; if other people came to them for advice on the issue; if they believed that others perceived them to be a good source of information; if they gave more information on global warming than they received in discussions; and how often they had discussed the issue over the past 2 weeks. All five items were coded bi-directionally, with positive scores indicating opinion leadership for mitigation; negative scores indicating opinion leadership against mitigation; and zero indicating no opinion leadership $(\alpha=.63)$.

Response efficacy was assessed with three measures asking how effective respondents believed the three activism behaviors would be on 4-point scales from "no effect" to "highly effective" $(\alpha=.90)$.

Self-efficacy was assessed indirectly as perceived barriers to climate activism because our data set did not include more direct measurements for the construct; a total of 25 barriers to the three behaviors were assessed, encompassing low skills, interest, perceived response efficacy, and identity $(\alpha=.72)$.

\subsection{Treatment of the Data}

The data were weighted using demographic distributions from the most recent Current Population Survey to yield nationally representative results. ${ }^{6}$ The model in Fig. 1 was tested in AMOS 19.0 using unweighted data ${ }^{7}$ and only those respondents who believe climate change is occurring because those who do not believe it's occurring are unlikely climate activists. We assessed the roles of the constructs in the model several ways: A confirmatory factor analysis of the measurement model tested the adequacy of the measures for each construct, and a one-factor model assessed whether all indicators in the model could be treated as components of a single factor. Reduced models were assessed, comparing the amount of variance in activism explained by demographics, values and key beliefs. ${ }^{8}$ Finally, the full model was fitted to the data, indicating the degree to which the mediators and second-stage processing variables explain additional variance in activism, beyond values and key beliefs.

\section{Results}

Climate activism: Of the 2,164 respondents, 16.9 percent $(N=365)$ had engaged in one or more of the three political activism behaviors at least once over the prior year (Table 1). Comparing respondents who had engaged in any form of activism to those who had not, we found that activists had more education $(t=8.34 * * *)^{9}$ and higher incomes $(t=3.44 * * *) ; 57$ percent of the activists were female, compared to 51 percent of the non-activists $\left(X^{2}=5.24^{*}\right)$.

Key beliefs and activism mediators: Activists had significantly higher means than non-activists on all key belief measures; the key beliefs in combination were related to much higher levels of climate activism (Table 2). Activists had significantly higher means on all mediators and

\footnotetext{
${ }^{6}$ Data were weighted by gender; age; race/Hispanic ethnicity; education; census region; metropolitan area; and internet access.

${ }^{7}$ AMOS is unable to work with weighted data.

${ }^{8}$ We will compare the variance explained by the various reduced models, but not the fit, as fit comparisons can only be made between models containing the same variables, but different paths.

${ }^{9}$ For all statistical tests, ${ }^{*} p<.05 ; * * p<.01 ; * * * p .001$.
} 
Table 1 Climate change political activism

Proportions Scale mean Scale SD

\begin{tabular}{|c|c|c|c|}
\hline $\begin{array}{l}\text { Vritten letters, emailed, or phoned government officials to urge } \\
\text { them to take action to reduce global warming }\end{array}$ & & & \\
\hline Intend to act less frequently & 16.2 & 2.21 & 1.14 \\
\hline Have not acted \& intend to do same & 66.8 & & \\
\hline Have not acted, but intend to act & 9.3 & & \\
\hline Have acted and intend to do same or more & 7.7 & & \\
\hline $\begin{array}{l}\text { Volunteered with or donated money to an organization working } \\
\text { to reduce global warming }\end{array}$ & & & \\
\hline Intend to act less frequently & 15.6 & 2.35 & 1.26 \\
\hline Have not acted \& intend to do same & 61.4 & & \\
\hline Have not acted, but intend to act & 11.0 & & \\
\hline Have acted and intend to do same or more & 12.0 & & \\
\hline Attended a community meeting or rally about global warming ${ }^{\mathrm{a}}$ & & & \\
\hline Intend to act less frequently & 16.3 & 2.14 & .98 \\
\hline Have not acted \& intend to do same & 66.6 & & \\
\hline Have not acted, but intend to act & 11.5 & & \\
\hline Have acted and intend to do same or more & 5.6 & & \\
\hline Totals & & & \\
\hline Intend to act less frequently (on all 3 measures) & 13.6 & 1.35 & .92 \\
\hline Have not acted \& intend to do same (on all 3 measures) & 54.4 & & \\
\hline Have not acted, but intend to act (one or more measures) & 15.2 & & \\
\hline Have acted and intend to do same or more (one or more measures) & 16.9 & & \\
\hline
\end{tabular}

a Scales for the three type of behavior have seven points (1 to 7); four categories have been collapsed in this table: Those who have acted once $\&$ intend to do the same; acted once $\&$ intend to do more; acted more than once $\&$ intend to do same; acted more than once $\&$ intend to do more. The Total scale, encompassing all three types of activism, has only four scale points, as shown. All means and SDs use the full scales - from 1 to 7 for the individual action scales and from 1 to 4 for the total action scale $(\mathrm{N}=2,164)$

second-stage variables as well: They were more emotionally engaged with the issue, wished to see more action to address the issue; had higher opinion leadership, civic engagement, and climate activism response efficacy; and they perceived fewer barriers (Table 3).

Structural equation modeling of political activism: Respondents who did not believe global warming is happening were dropped from the analysis, leaving $N=1,706$ for the modeling.

Measurement model: The omnibus confirmatory factor analysis model contained all indicators of the latent constructs, omitting the observed variables $\left(X^{2}=3124.78(d f=329)^{* * *} ; X^{2} / d f=9.50\right.$; $R M S E A=.071 ; C F I=.905)$. Modification indices suggested the fit could be improved by freeing four correlated error terms, ${ }^{10}$ and when these were freed, the data were found to be consistent with the model $\left(X^{2}=1473.32(d f=325)^{* * *} ; X^{2} / d f=4.53 ; R M S E A=.046 ; C F I=.971\right)$. See Supplemental Materials for detail on this and all subsequent models.

\footnotetext{
${ }^{10}$ The correlated errors have substantive meaning and are not simply statistical artifacts: Correlated errors of the injunctive belief measures linked higher desire for action from President Bush \& the U.S. Congress; state legislators and local government; and corporations and citizens. Two opinion leadership measures were also linked: Being a source of advice and being perceived as a good source.
} 
Table 2 Key beliefs about global warming

\begin{tabular}{|c|c|c|c|c|c|}
\hline & & \multicolumn{3}{|l|}{ Means } & \multirow[t]{2}{*}{$\mathrm{t}$ or $\mathrm{X}^{2 * * *}$} \\
\hline & & Population & Climate activists & Non-activists & \\
\hline \multirow{2}{*}{$\begin{array}{l}\text { Certainty that warming is/is } \\
\text { not occurring (9-pt. scale) }\end{array}$} & Mean & 6.88 & 8.08 & 6.64 & \multirow[t]{2}{*}{16.82} \\
\hline & $S D$ & 2.07 & 1.33 & 2.11 & \\
\hline \multirow{2}{*}{$\begin{array}{l}\text { Mean risk perception } \\
\text { (standardized index } \\
\text { of } 23 \text { items) }\end{array}$} & Mean & .00 & .89 & -.12 & \multirow[t]{2}{*}{19.73} \\
\hline & $S D$ & .88 & .53 & .89 & \\
\hline $\begin{array}{l}\text { Humans cause global } \\
\text { warming (dichotomous) }\end{array}$ & $\%$ Correct & .57 & .80 & .52 & 93.88 \\
\hline \multirow{2}{*}{$\begin{array}{l}\text { Humans can reduce global } \\
\text { warming (5-pt. scale) }\end{array}$} & Mean & 3.36 & 3.88 & 3.25 & \multirow[t]{2}{*}{15.82} \\
\hline & $S D$ & .99 & .60 & 1.02 & \\
\hline \multirow{2}{*}{ Conjoint effects of key beliefs } & & \multirow{2}{*}{$\%$ of Population } & \multicolumn{2}{|c|}{$\begin{array}{l}\text { Proportions of those } \\
\text { holding beliefs shown } \\
\text { in left column who are... }\end{array}$} & \multirow[t]{2}{*}{$X^{2}$} \\
\hline & & & Climate activists & Non-activists & \\
\hline Holds none of the key beliefs & $\%$ & 19.4 & 2.9 & 97.1 & 245.89 \\
\hline $\begin{array}{l}\text { Certain that warming is } \\
\text { occurring ( } 8 \text { or } 9 \text { on scale) }\end{array}$ & $\%$ & 3.6 & 2.5 & 97.5 & \\
\hline $\begin{array}{l}\text { Certain and holds high risk } \\
\text { perceptions (top quartile) }\end{array}$ & $\%$ & 1.4 & 3.2 & 96.8 & \\
\hline $\begin{array}{l}\text { Certain, holds high risk } \\
\text { perceptions and recognizes } \\
\text { human causation }\end{array}$ & $\%$ & 4.1 & 32.6 & 67.4 & \\
\hline Holds all four key beliefs & $\%$ & 14.4 & 40.2 & 59.8 & \\
\hline $\begin{array}{l}\text { Certain, recognizes human } \\
\text { causation and solvability, but } \\
\text { holds lower risk perceptions } \\
\text { (bottom } 75 \% \text { ) }\end{array}$ & $\%$ & 13.9 & 26.8 & 73.2 & \\
\hline All others & $\%$ & 43.1 & 12.3 & 87.7 & \\
\hline
\end{tabular}

***Activists are defined here as individuals who have taken any of the three forms of climate action in the past year at least once; activism intentions are not included in this analysis . T-tests were used for comparisons of ordinal data; chi-square tests were used for nominal data. All comparisons in the table are significant at $p<.001$. $(N=2,164)$

Key beliefs and values models: We fitted three models initially: In the first, values and demographics predicted activism; in the second, key beliefs and demographics were the predictors; and in the third, values, key beliefs and demographics were all included.

Seventeen percent of the variance in climate activism was explained by values (egalitarianism $\beta=.23 * * *$; individualism $\beta=-.11^{* *}$ ); and demographics (education $\beta=.21^{* * *}$; age $\beta=.08^{* *}$; income $\left.\beta=.06^{* *}\right)$. Twenty-one percent was explained by three key beliefs (belief certainty $\beta=.12^{* * *}$; risk perceptions $\beta=.29 * * *$; collective efficacy $\beta=.08^{* *}$ ); and education $\left(\beta=.11^{* * *}\right)$. The model containing values, key beliefs and demographics explained 24 percent of the variance in activism: (egalitarianism $\beta=.11^{* * *}$; certainty $\beta=.10^{* * *}$; risk perceptions $\beta=.24 * * *$; collective efficacy $\beta=.06^{*}$; education $\beta=.19^{* * *}$; income $\beta=.06^{*}$; age $\left.\beta=.06^{*}\right)$. Thus, the key beliefs were stronger predictors of activism than values, and the addition of values to key beliefs as activism predictors added only an additional 3 percent of explained variance. 
Table 3 Second-stage activism predictors

\begin{tabular}{|c|c|c|c|c|c|c|}
\hline & & & \multicolumn{3}{|l|}{ Means } & \multirow[t]{2}{*}{$\mathrm{t}^{* * *}$} \\
\hline & & & Population & $\begin{array}{l}\text { Climate } \\
\text { activists }\end{array}$ & $\begin{array}{l}\text { Non- } \\
\text { activists }\end{array}$ & \\
\hline \multirow[t]{4}{*}{ Affective issue involvement } & \multirow[t]{2}{*}{ Worry (4 pt. scale) } & Mean & 2.66 & 3.23 & 2.54 & 16.96 \\
\hline & & $S D$ & .91 & .66 & .91 & \\
\hline & \multirow{2}{*}{$\begin{array}{l}\text { Personal importance } \\
\quad(5 \text { pt. scale })\end{array}$} & Mean & 3.01 & 3.75 & 2.86 & 17.21 \\
\hline & & $S D$ & 1.12 & .86 & 1.11 & \\
\hline \multirow{14}{*}{$\begin{array}{l}\text { Injunctive beliefs (Should the } \\
\text { following be doing more or less } \\
\text { to address global warming? } \\
\text { ( } 5 \text { pt. scales) }\end{array}$} & \multirow[t]{2}{*}{ Corporations } & Mean & 3.97 & 4.55 & 3.85 & 14.97 \\
\hline & & $S D$ & 1.13 & .71 & 1.16 & \\
\hline & \multirow[t]{2}{*}{ Citizens themselves } & Mean & 3.87 & 4.45 & 3.74 & 16.17 \\
\hline & & $S D$ & 1.04 & .67 & 1.06 & \\
\hline & \multirow[t]{2}{*}{ The President (GW Bush) } & Mean & 3.75 & 4.47 & 3.60 & 18.41 \\
\hline & & $S D$ & 1.13 & .72 & 1.14 & \\
\hline & \multirow[t]{2}{*}{ The U.S. Congress } & Mean & 3.73 & 4.41 & 3.59 & 17.50 \\
\hline & & $S D$ & 1.11 & .72 & 1.12 & \\
\hline & \multirow[t]{2}{*}{ Your governor } & Mean & 3.61 & 4.15 & 3.49 & 14.74 \\
\hline & & $S D$ & 1.01 & .71 & 1.03 & \\
\hline & \multirow[t]{2}{*}{ State legislators } & Mean & 3.61 & 4.17 & 3.49 & 15.05 \\
\hline & & $S D$ & 1.01 & .71 & 1.03 & \\
\hline & \multirow[t]{2}{*}{ Local government } & Mean & 3.53 & 3.98 & 3.44 & 11.31 \\
\hline & & $S D$ & 1.00 & .79 & 1.01 & \\
\hline \multirow[t]{2}{*}{ Civic engagement } & \multirow{2}{*}{$\begin{array}{l}\text { Civic engagement index } \\
\quad(\text { range }=0 \text { to } 9)\end{array}$} & Mean & .78 & 1.84 & .56 & 12.07 \\
\hline & & $S D$ & 1.43 & 1.94 & 1.19 & \\
\hline \multirow[t]{10}{*}{ Opinion leadership } & \multirow{2}{*}{$\begin{array}{l}\text { Discussed in last } 2 \text { weeks } \\
\text { (7-pt. scale: }-3 \text { to }+3)\end{array}$} & Mean & .38 & .92 & .26 & 18.30 \\
\hline & & $S D$ & .67 & .77 & .59 & \\
\hline & \multirow{2}{*}{$\begin{array}{l}\text { Like to discuss } \\
\text { (3-pt. scale: }-1 \text { to }+1)\end{array}$} & Mean & .23 & .59 & .16 & 15.50 \\
\hline & & $S D$ & .45 & .50 & .40 & \\
\hline & \multirow{2}{*}{$\begin{array}{l}\text { Give more info than } \\
\text { receive }(5 \text {-pt. scale: }-2 \text { to }+2)\end{array}$} & Mean & .44 & .94 & .34 & 14.37 \\
\hline & & $S D$ & .75 & .72 & .72 & \\
\hline & \multirow{2}{*}{$\begin{array}{l}\text { Perceived by others as good } \\
\text { source (3-pt. scale: }-1 \text { to }+1)\end{array}$} & Mean & .04 & .12 & .02 & 5.24 \\
\hline & & $S D$ & .23 & .34 & .20 & \\
\hline & \multirow{2}{*}{$\begin{array}{l}\text { Others come to respondent for } \\
\text { advice (3-pt. scale: }-1 \text { to }+1)\end{array}$} & Mean & .06 & .21 & .03 & 8.06 \\
\hline & & $S D$ & .29 & .41 & .24 & \\
\hline \multirow{6}{*}{$\begin{array}{l}\text { Response efficacy (How effective } \\
\text { would the following be? } \\
\text { (4 pt. scales)) }\end{array}$} & \multirow[t]{2}{*}{ Contacting officials } & Mean & 1.57 & 2.17 & 1.44 & 13.68 \\
\hline & & $S D$ & .96 & .92 & .92 & \\
\hline & \multirow[t]{2}{*}{ Donating time/money } & Mean & 1.70 & 2.48 & 1.54 & 16.32 \\
\hline & & $S D$ & 1.06 & .98 & 1.00 & \\
\hline & \multirow[t]{2}{*}{ Attending rallies/meetings } & Mean & 1.52 & 2.08 & 1.41 & 12.20 \\
\hline & & $S D$ & .95 & .96 & .90 & \\
\hline \multirow[t]{2}{*}{ Barriers ( 25 possible) } & Number of perceived barriers & Mean & 3.47 & 2.65 & 3.64 & 7.12 \\
\hline & & $S D$ & 2.97 & 2.26 & 3.07 & \\
\hline
\end{tabular}

***Activists are defined here as individuals who have taken any of the three forms of climate action in the past year at least once; activism intentions are not included in this analysis. In all $t$-tests contrasting activists with nonactivists, comparison is significant, $p<.001$. $(N=2,164)$ 
Full model: The initial test of the full structural model included the measurement model, theory-specified structural paths, and the demographic controls $\left(X^{2}=3184.45(d f=631) * * * ; X^{2} /\right.$ $d f=5.05 ; \mathrm{RMSEA}=.049 ; C F I=.926)$. The initial fit of the data to the model suggested several improvements, which were implemented to develop Fig. 2; this model explained 52 percent of the variance in climate activism, and was judged a good fit to the data $\left(X^{2}=2278.75(d f=\right.$ $526)^{* * *} ; X^{2} / d f=4.33 ; R M S E A=.044 ; C F I=.948$ ). Non-significant paths were dropped from involvement to activism and from injunctive beliefs to opinion leadership. The modification indices indicated a direct influence of certainty that global warming is occurring on opinion leadership, which has been added.

Gender was the only demographic significantly related to activism in the full model; modification indices showed it was related to egalitarianism and risk perceptions as well, with women higher on all three variables, findings that are consistent with prior research on gender, values and risk perceptions. These paths were added to the model; all other demographics were dropped from the final model for simplicity (Table 4). ${ }^{11}$

All four key beliefs were significant predictors of issue involvement and injunctive beliefs, with risk perceptions having the strongest impact. Together, they explained 39 percent of the variance in injunctive beliefs and 68 percent of the variance in affective involvement. Involvement and a history of civic engagement together explained 44 percent of the variance in opinion leadership, which in turn explained 22 percent of the variance in activism response efficacy. Opinion leadership explained only 4 percent of the variance in self-efficacy. Finally, 52 percent of the variance in climate activism was explained by six variables: Opinion leadership, civic engagement, activism response efficacy, injunctive beliefs, perceived barriers and gender.

In summary, the key beliefs and demographics explained 24 percent of the variance in activism, and the second-stage variables added an additional 28 percent of explained variance.

\section{Discussion}

Examples of a growing U.S. climate movement are numerous: Protests against the Keystone XL pipeline drew an estimated 40,000 people to the National Mall in Feb. 2013, and a million comments were submitted to the State Department opposing the pipeline by late April; a national anti-coal campaign has shut down hundreds of existing and proposed coal-fired power plants; over 10,000 congregations have come together under the umbrella of Interfaith Power and Light to activate faith communities; and a growing student and popular movement is pressuring universities, faith communities and cities to divest from fossil fuels.

The Congress, however, remains deadlocked on the issue, with climate skeptics blocking action. In light of research arguing that a legislative response to climate change is unlikely without increased levels of civic activism, we have examined some of the cognitive processes that motivate people to become involved; below, we explore the implications.

\subsection{Balancing risk and efficacy}

The key beliefs - that climate change is real, human caused, dangerous, and solvable - have been emphasized, to differing degrees, by communicators for some time. This analysis

${ }^{11}$ Education significantly predicted civic engagement, but was not directly related to activism; hence, it was dropped. 


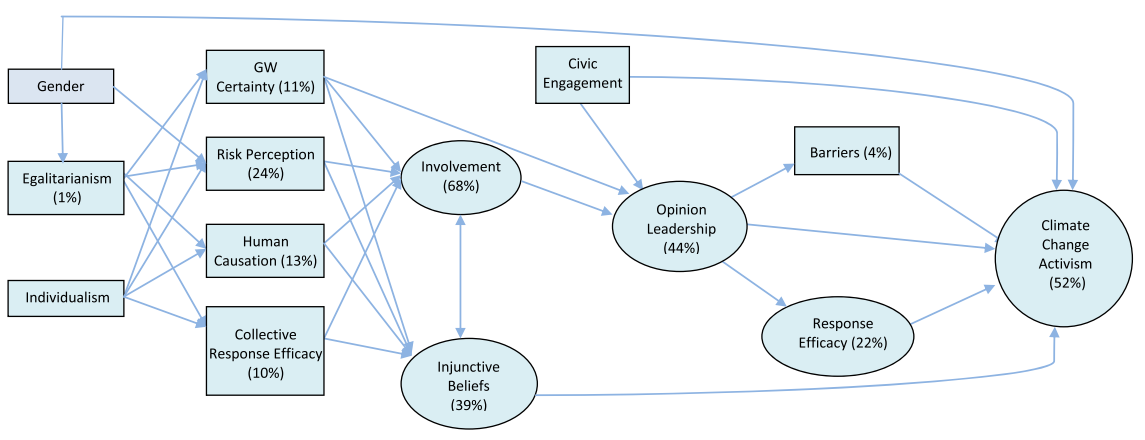

Chi-square $=2285.38 ; \mathrm{df}=526, p<.001 ; \mathrm{N}=1,784$

RMSEA $=.044 ; \mathrm{CFI}=.948$

Variance explained $\left(R^{2}\right)$ is shown in parentheses.

All standardized path coefficients are significant at $p<.001$.

Ovals represent latent variables and rectangles represent measured

variables

Fig. 2 Structural Model of Political Activism for Climate Change Mitigation

confirms that these are important messages; the emphasis, however, has often been on the first three beliefs, with less attention given to solvability.

Surveys show that risk perceptions have increased over the past 5 years in the U.S. although still not necessarily achieving a level that accurately reflects the magnitude of the risk - while beliefs that individual action can make a difference have declined (Leiserowitz et al. 2012b). Collective efficacy is also low: A fifth (22\%) of our respondents believed that society could reduce global warming, but won't because people are unwilling to change their behavior. Half said it's unclear what society will do, while only six percent said society can and will. Communicators face a public in which some are frightened and despairing, while others do not recognize there is cause for concern: Addressing the latter with messages about climate impacts runs the risk of increasing despair in the former, unless messages are accompanied by credible, achievable solutions.

With survey data we cannot assess whether people with high risk and low efficacy perceptions are responding to the issue by defensive avoidance, but our results do suggest that high risk perceptions alone are not enough to motivate action: Respondents with high risk perceptions, but who did not believe that humans are causing the problem or could solve it were no more likely to have taken action than people who were not certain global warming is happening (Table 2). Only 3 percent of this group had engaged in some type of activism, compared to 40 percent of the group with all four key beliefs. ${ }^{12}$

A clear implication is that climate communicators should work to build a sense of efficacy among their audiences. One possible strategy is to present efficacy-building information first, followed by information on the threat. The Science Museum of Minnesota's climate change exhibit, for example, begins with efficacy-building and then turns to climate impacts. Their surveys show that climate change beliefs among museum visitors mirror national benchmarks, but a 2011 evaluation of the exhibit found that 60 percent of the visitors felt hopeful after seeing the presentation (Phipps

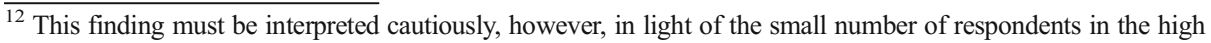
risk, low efficacy group $(n=31)$. 
Table 4 Standardized regression weights for the structural model shown in fig. 2

\begin{tabular}{|c|c|c|c|}
\hline Dependent variables & Predictors & Standardized regression weights & Variance explained \\
\hline Egalitarianism & Gender (female) & $.08 * *$ & .01 \\
\hline \multirow[t]{2}{*}{ GW certainty } & Egalitarianism & $.14 * * *$ & .11 \\
\hline & Individualism & $-.23 * * *$ & \\
\hline \multirow[t]{3}{*}{ Risk perceptions } & Gender (female) & $.09 * * *$ & .24 \\
\hline & Egalitarianism & $.37 * * *$ & \\
\hline & Individualism & $-.14 * * *$ & \\
\hline \multirow[t]{2}{*}{ Human causation } & Egalitarianism & $.20 * * *$ & .13 \\
\hline & Individualism & $-.20 * * *$ & \\
\hline \multirow[t]{2}{*}{ Collective efficacy } & Egalitarianism & $.17 * * *$ & .10 \\
\hline & Individualism & $-.18 * * *$ & \\
\hline \multirow[t]{4}{*}{ Issue involvement } & GW certainty & $.25 * * *$ & .68 \\
\hline & Risk perceptions & $.56 * * *$ & \\
\hline & Human causation & $.11 * * *$ & \\
\hline & Collective efficacy & $.11 * * *$ & \\
\hline \multirow[t]{4}{*}{ Injunctive beliefs } & GW certainty & $.12 * * *$ & .39 \\
\hline & Risk perceptions & $.37 * * *$ & \\
\hline & Human causation & $.11 * * *$ & \\
\hline & Collective efficacy & $.21 * * *$ & \\
\hline \multirow[t]{3}{*}{ Opinion leadership } & GW certainty & $.15 * * *$ & .44 \\
\hline & Issue involvement & $.45^{* * *}$ & \\
\hline & Civic engagement & $.37 * * *$ & \\
\hline Perceived barriers & Opinion leadership & $-.19 * * *$ & .04 \\
\hline Response efficacy & Opinion leadership & $.47 * * *$ & .22 \\
\hline \multirow[t]{6}{*}{ Global warming political activism } & Gender (female) & $.07 * *$ & .52 \\
\hline & Civic engagement & $.25 * * *$ & \\
\hline & Injunctive beliefs & $.13 * * *$ & \\
\hline & Opinion leadership & $.42 * * *$ & \\
\hline & Response efficacy & $.18 * * *$ & \\
\hline & Perceived barriers & $-.06 * *$ & \\
\hline
\end{tabular}

${ }^{*} p<.05 ; * * p<.01 ; * * * p<.001$

and King 2011), as compared to 47 percent of Americans nationally (Leiserowitz et al. 2010). This was not a formal test of efficacy-building, but it suggests that a larger-scale assessment of this idea would be useful.

\subsection{Opinion leadership}

Global warming opinion leadership - defined in terms of interpersonal discussion and selfperceived interpersonal influence - was the strongest direct predictor of climate activism, mediating the influence of involvement on activism. Studies have long shown that people are more influenced by those they know than any other source: Only climate scientists are more trusted on global warming than interpersonal contacts (82\% vs. $77 \%$, respectively; Leiserowitz et al. 2009). 
Building opinion leadership on the issue - e.g., by encouraging those who are concerned about the issue to discuss it with their friends and family, and eventually with other more socially distal people - may be one of the most effective methods of building public engagement and political activism: Network analyses have shown that interpersonal influence in arenas as diverse as obesity, happiness and cooperation extends as far as 1,000 people and three-degrees of separation (Fowler and Christakis 2010). Simply understanding this fact can build the opinion leader's sense of the significance and effectiveness of personal action.

\subsection{Barriers and activism outcome expectations:}

Of the barriers to activism we assessed, identity was the largest, with a third of respondents (33\%) saying they were not activists. Studies of social movements show that an important motivation for participation is the strengthening of identity (Klandermans 2004), and one strategy for building a broad-based climate campaign could be to employ spokespeople a wide range of people can or would like to identify with e.g., activist mothers, doctors, celebrities, high school students, etc.

Relatively few respondents viewed any form of activism as effective: Donations were viewed as "highly" or "pretty" effective by 22 percent of the respondents; contacting government officials by 15 percent; and attending rallies by 12 percent. Almost three-quarters ( $74 \%)$ said none of the three forms of activism would have much effect; altering these perceptions should be an important objective for climate communicators. Email and social media postings touting movement success are commonly used by environmental organizations for this purpose, and evaluations of their effectiveness would be useful.

\subsection{Caveats}

These data are cross-sectional, so the causal pathways we postulate oversimplify relationships. A longitudinal study would likely identify feedbacks among the variables in the model, with political activism strengthening issue involvement, opinion leadership and injunctive beliefs, and decreasing perceived barriers, for example; opinion leadership and civic engagement effects are likely to be bi-directional as well. This is consistent with Bandura's concept of reciprocal causation, as well as numerous studies demonstrating bi-directional effects over time. Our model, however, focuses on the factors leading people to become climate activists, rather than increasing activism among those who are already engaged, so feedbacks are less relevant to our purpose.

A second caveat is that the model addresses only mitigation - not adaptation. The role of human causation and collective efficacy for reducing climate change are unlikely to play such important roles in support for adaptation; a substantial portion of the public still believes that climate change is being caused by natural changes in the environment, and these individuals may support action to adapt to climate change, even as they oppose policies to mitigate it.

\section{Conclusion}

Together, the analyses suggest that those working to build a broad, sustained climate movement should continue to emphasize the key beliefs identified in this study, as well as the widespread agreement among scientists on these issues, a perception shown to significantly increase all four beliefs (Ding et al. 2011). The threat posed by climate change should continue 
to be a component of climate change messaging, but should be accompanied - and perhaps even preceded - by messages on effective actions individuals can take.

This alone is insufficient, however: The results suggest that supporting public beliefs about the effectiveness and feasibility of activism is also central. Americans perceive multiple barriers to political participation, and have low expectations for the effectiveness of their actions. Campaigns should encourage interpersonal discussion of the issue to build affective involvement and opinion leadership, and to spread the influence of those who are already engaged with the issue to their social networks.

We conclude with a prescient quote from Bandura, pointing to the importance of building a sense of collective efficacy. While risk perceptions may provide the motivation to search for climate solutions, collective efficacy is likely to determine the success of these efforts:

Our own collective efficacy will...shape how future generations live their lives. Considering the pressing worldwide problems that loom ahead, people can ill-afford to trade efficacious endeavor for public apathy or mutual immobilization. The times call for a commitment of collective effort rather than litanies about powerlessness that instill in people beliefs of inefficacy to influence conditions that shape their lives (1986, p. 453).

Acknowledgments The authors wish to thank the two anonymous reviewers for their comments, which were very helpful.

Open Access This article is distributed under the terms of the Creative Commons Attribution License which permits any use, distribution, and reproduction in any medium, provided the original author(s) and the source are credited.

\section{References}

Adams J, Ezrow L (2009) Who do European parties represent? How Western European parties represent the policy preferences of opinion leaders. J Polit 71(1):206-223

Allum N, Sturgis P, Tabourazi D, Brunton-Smith I (2008) Science knowledge and attitudes across cultures: a meta-analysis. Public Underst Sci 17:35-54

Bain P, Honsey M, Bongiorno R, Jeffries C (2012) Promoting pro-environmental action in climate change deniers. Nat Clim Change 2:600-603

Bandura A (1977) Social learning theory. General Learning Press, NY

Bandura A (1986) Social foundations of thought and action: a social cognitive theory. Prentice Hall, Englewood Cliffs, NJ

Bandura A (2000) Exercise of human agency through collective efficacy. Curr Dir Psychol Sci 9(3):75-78

Brady H, Verba S, Schlozman K (1995) Beyond SES: a resource model of political participation. Am Polit Sci Rev 89(20):271-294

Burstein P, Einwohner R, Hollander J (1995) The success of political movements: a bargaining perspective. In: Jenkins JC, Klandermans B (eds) Politics of social protest: comparative perspectives on states and social movements. University of Minnesota Press, Minneapolis, pp 275-295

Chaffee S, Roser C (1986) Involvement and the consistency of knowledge, attitudes, and behaviors. Commun Rsch 13:373-400

Ding D, Maibach E, Zhao X, Roser-Renouf C, Leiserowitz A (2011) Support for climate policy and societal action are linked to perceptions about scientific agreement. Nat Clim Chang 1:462-466

Finkel S, Muller E, Opp K-D (1990) Personal influence, collective rationality, and mass political action. Am Polit Sci Rev 83(3):885-903

Fowler J, Christakis N (2010) Cooperative behavior cascades in human social networks. PNAS 107:12

Kahan D, Jenkins-Smith H, Braman D (2010) Cultural cognition of scientific consensus. J Risk Res 14(2):157-174

Klandermans B (2004) The demand and supply of participation: social-psychological correlates of participation in social movements. In: Snow D, Soule S, Kriesi H (eds) The Blackwell companion to social movements. Blackwell, NY, pp 360-379 
Krosnick J, Holbrook A, Lowe L, Visser P (2006) The origins and consequences of democratic citizen's policy agenda: a study of popular concern about global warming. Clim Chang 77:7-43

Kunda Z (1990) The case for motivated reasoning. Psychol Bull 3:480-498

Leiserowitz A (2005) American risk perceptions: is climate change dangerous? Risk Anal 25:1433-1442

Leiserowitz A, Maibach E, Roser-Renouf C et al. (2009) (multiple citations). Climate change in the American mind. Yale University and George Mason University. New Haven, CT: Yale Project on Climate Change Communication. Accessed 7 July 2013 www.climatechangecommunication.org/images/files/Climate Change in the American_Mind.pdf

Leiserowitz A, Maibach E, Roser-Renouf C et al. (2012a) http://environment.yale.edu/climate-communication/ files/Behavior-September-2012.pdf

Leiserowitz A, Maibach E, Roser-Renouf C et al. (2012b) http://environment.yale.edu/climate-communication/ files/Climate-Beliefs-September 2012.pdf

Leiserowitz A, Maibach E, Roser-Renouf C et al. (2010) (multiple Citations). Global warming's Six Americas. Yale University and George Mason University. New Haven, CT: Yale Project on Climate Change Communication. Accessed 7 July 2013 http://environment.yale.edu/climate/files/SixAmericasJune2010.pdf

Leiserowitz A, Maibach E, Roser-Renouf C et al. (2013) http://environment.yale.edu/climate-communication/ files/Six-Americas-September-2012.pdf

Lorenzoni I, Nicholson-Cole S, Whitmarsh L (2007) Barriers perceived to engaging with climate change among the UK public and their policy implications. Global Environ Chang 17(3-4):445-459

Lubell M (2002) Environmental activism as collective action. Environ Behav 34(4):431-454

Lubell M, Zahran S, Vedlitz A (2007) Collective action and citizen responses to global warming. Polit Behav 29: $391-413$

Maibach E, Roser-Renouf C, Leiserowitz A (2008) Communication and marketing as climate change intervention assets: A public health perspective. American Journal of Preventive Medicine 35(5):488-500

McLeod J, Scheufele D, Moy P (1999) Community, communication and participation: the role of mass media and interpersonal discussion in local political participation. Polit Commun 16:315-336

Myers T, Maibach E, Roser-Renouf C, Akerlof K, Leiserowitz A (2013) Personal experience or belief in the reality of global warming: Which comes first? Nat Clim Chang 3:343-347

Ockwell D, Whitmarsh L, O’Neill S (2009) Reorienting climate change communication for effective mitigation: forcing people to be green or fostering grass-roots engagement? Sci Commun 30:305-327

Petty R, Cacioppo J (1986) Attitudes and persuasion: classic and contemporary approaches. Wm Brown, Dubuque

Pew Research Center for People and the Press, March 22, 2007. Trends in Political Attitudes and Core Values: 1997-2007. http://people-press.org/report/312/trends-in-political-values-and-coreattitudes-1987-2007 Accessed 9 July 2013

Phipps M, King Z (2011) Planet earth decision theater live performance: Formative evaluation. Available at: http://archive.informalscience.org/reports/0000/0582/PEDT_Theater_formativeFINAL.pdf

Scheufele D, Shah D (2000) Personality strength and social capital: the role of dispositional and informational variables in the production of civic participation. Commun Res 27:107-131

Schwebel M (2008) Peace activists: maintaining morale. Peace Confl 14(2):215-224

Shah D, Scheufele D (2006) Explicating opinion leadership: nonpolitical dispositions, information consumption, and civic participation. Polit Commun 23(1):1-22

Skocpol T (2013) Naming the problem: What it will take to counter extremism and engage Americans in the fight against global warming. Harvard Symposium on The Politics of America's Fight Against Global Warming. http:/www.scholarsstrategynetwork.org/sites/default/files/skocpol_captrade_report_january_2013_0.pdf Accessed 9 July 2013

Stern P, Dietz T, Abel T, Guagnano G, Kalof L (1999) A value-belief-norm theory of support for social movements: the case of environmentalism. Hum Ecol Rev 6:81-97

Stoll-Kleeman S, O'Riordan T, Jaeger C (2001) The psychology of denial concerning climate mitigation measures: evidence from swiss focus groups. Global Environ Chang 11:107-117

Verba S, Schlozman K, Brady H (1995) Voice and equality: civic volunteerism in American politics. Harvard Univ, Press, Cambridge

Weimann G (1991) The influentials: back to the concept of opinion leaders? Public Opin Quart 55(2):267-279

Witte K, Allen M (2000) A meta-analysis of fear appeals: implications for effective public health campaigns. Health Educ Beh 27(5):591-615 